Diest, in the Bolderian white sands, a fossiliferous bed not near to the top of the formation. Last summer the Belgian Geological Society made an excursion to those localities, with a view to observe again the exact position of the fossiliferous bed. The sections were exposed afresh, and all the geologists present, Mr. Lorié, from Utrecht, Mr. Lohest, pupil of Mr. Dewalque, Mr. Vincent, palæontologist, and many otber distinguisbed Belgian geologists, also the writer of the present letter, came to the same conclusion, namely, that the fossiliferous bed is inclosed in the white sands, exactly as had been stated by Dumont many years ago.

When my honoured friend, Prof. Dewalque, says that in the eastern direction, near the valley of the Rhine, the white Bolderian sands contain Tongrian fossils, this is only an affirmation, but no evidence in favour of this statement has ever been produced. We should be very pleased to make the acquaintance of any geologist who has been so fortunate as to follow step by step the Bolderian sands from Hasselt to the Rhine!

The most recent observations seen to prove, on the contrary, that Dumont made in bis Bolderian a great inversion ; his Upper fluviomarine stage is really the Lower one, and the marine shales are the Upper. The fluviatile Bolderian has been recognized in boring under Campine and Limbourg, and probably it is associated with the Rhenan lignites; it might take the name of Aquitanian. But this question is not yet perfectly solved. Last month Mr. Van den Broeck came to the conclusion that the Bolderian sands were very close to the Upper Rupelian sands, and that all these sands were united, by repeated alternation, with the Rupelian clay (Argile de Boom) and by no means form a good horizon. But even if the fluviatile Bolderian is not valid and is a bad subdivision, containing sands which can be better classified in three or more different stages, it remains always a good marine Bolderian, a sound type well characterized by its palæontology, and indicated by its stratigraphy. We think that we can, without any hesitation, maintain the old name of "Bolderian" in its true, original acceptation.

G. F. Dollfus, F.C.G.S.

Paris, 10 Janvier, 1896. Président de la Société Géologique de France.

OBITUAFY.

\title{
HUGH MILLER, F.R.S.E., F.G.S.
}

\author{
Born July 15Th $1850 . \quad$ Died Januaky 8Th, 1896.
}

Ix is with great regret that we record the death of Mr. Hugh Miller, F.R.S.E., F.G.S., of the Geological Survey of Scotland. Bearing the same name as his distinguished father, the author of "The Testimony of the Rocks," "The Old Red Sandstone," etc. Mr. Hugh Miller inherited a taste for geological pursuits, and joined the Geological Survey in 1874. Labouring at first among the Carboniferous Rocks and Glacial Dritts of Northumberland, he was subsequently transferred to the Geological Survey of Scotland, and worked at the Old Red Sandstone around Cromarty, rendered 
classic by the researches of his father. Later on he mapped portions of the Ancient Schists, Old Red Sandstone, and Drifts of Eastern Sutherlandshire. He was anthor of the picturesquelywritten book entitled "Landscape Geology," and of papers on River Action and Glacial Phenomena. Among the more important of these papers the following may be mentioned:- "Tynedale Escarpments : their Pre-glacial, Glacial, and Post-glacial Features," 1880 ; "River Terracing: its methods and their results," 1884; and "On Boulder-Glaciation," 1884." All who enjoyed Mr. Miller's friendship will feel that they have lost a kind-hearted, though keenly sensitive, friend. Strongly imbued with a love of Nature and natural phenomena, he at the same time kept himself in touch with the intellectual life of our time. He leaves a widow and a son, fifteen years of age, who is being educated at Fettes College.

\section{PROFESSOR LUDWIG RÜTIMEYER, M.D.}

Foreign Member of the Geological Society of London.

\section{BORN 1825. \\ Died November 26ri, 1895.}

Herr Professor Dr. Ludwig Rütimeyer was born at Biglen in the Commenthal, Canton Bern, in 1825. His father was a parish clergyman, and afterwards Superintendent of the Orphanage at Bonn. Ludwig was educated in the High School and Gymnasium of that town, and in 1842 went to the University of Berne, where he studied theology, with the intention of following his father's profession. - Having developed a taste for comparative anatomy, no doubt partly through the influence of his friend Peter Merian, the Basel Palæontologist, he forsook his theological studies, and took up medicine. Afterwards he visited many of the chief European cities, and in Paris in $\mathbf{1 8 5 0}$ he became acquainted with Elie de Beaumont, and in 1852 he came to London, which he again visited in 1877, In 1854 he took up academical teaching in the Berne University, and in the following year accepted the newly established Chair of Zoology and Comparative Anatomy at Basel, where he remained till his death.

His first work, "Vom Meere bis nach den Alpen," was published on his return from his travels in 1854 ; after this he issued a long series of Memoirs, characterized by the great accuracy and detail of their observations, and the wide philosophical grasp and far-reaching deductions made from them.

Some of the more important of these memoirs are:- "Untersuchungen der Thierreste aus dem Pfahlbauten in der Schweiz," 1860 , in which he gives an account of the earlier races of some of the domestic animals, and shows that while in the Lake-dwellings of Stone Age the remains of wild animals predominate, showing that the inhabitants lived mainly by the chase, in the later settlements, made after the use of metal was discovered, the inhabitants relied chiefly on various domesticated animals for food.

Another important paper is "Beitrage zur Kentnisse der Fossilen Pferde und zu einer Vergleichenden Odontographie der Hufthiere in Allgememen," 1863 ; this may be regarded as laying the foundation 